\title{
Perception of Students on Computer Utilization and Academic Performance in the North-Central Geopolitical Zone of Nigeria
}

\author{
Salako E. Adekunle \\ Department of Computer Science FCT College of Education, Zuba, Nigeria \\ Email: kunlesky2@gmail.com \\ Solomon A. Adepoju \& Muhammed B. Abdullahi \\ Department of Computer Science, Federal University of Technology Minna, Nigeria \\ Email:sa.adepoju@gmail.com, el.bashir02@gmail.com
}

\begin{abstract}
The introduction and application of computer as a resource in teaching and learning process in education has contributed to the achievement of educational objectives. Students at all levels of education use computers for specified purpose. Do computers really help students to achieve academic excellence? The study investigated the perception of students on computer utilization and academic performance. It is a descriptive research with emphasis on survey design. The population comprised all Colleges of Education in North Central geopolitical zone of Nigeria: made up of six states and FCT-Abuja; out of which six colleges were selected as sample. A 20-item questionnaire (CUSAPQ) was designed and validated through expert judgment and reliability co-efficient of 0.86 was obtained. The null hypotheses were tested using Chi-square and ANOVA statistical analysis at 0.05 level of significance. Findings revealed that there was positive perception of computer utilization on students' academic performance in the selected zone. Based on the findings, recommendations were made; seminar and workshops on computer utilization should be organised for the lecturers and the students to facilitate active and effective learning.
\end{abstract}

Index terms - Perception, Students, Computer utilization, Academic performance, Teaching, Learning, Internet, Education, Colleges of Education.

\section{INTRODUCTION}

The introduction and development of western education in Nigeria by the missionaries and the colonial administration cannot be treated in isolation from traditional form of education. The traditional education was a way by which the learners acquired knowledge without well-predefined formats of instructions delivery. This form of education could take place under a tree, car garage; and was basic form of education before the western education was introduced. The learners in Nigeria used various media and objects such as drums, flutes, gongs etc; for communication and the classrooms' discussion was not left out. Objects such as stones and sticks were used to count numbers. The use of writing and invention of printing materials transformed the type and context of recorded history communication in a tremendous progression. Through the utilization of books, newspapers, magazines and radio; instructions were given to students at different levels of education. The western education is now supported and enhanced with the application of computer in teaching and learning process.

According to [13], the fast progress of technology and its wide integration in education has been changed in recent years. The advancement in technology has facilitated in the development of many Information and Communication Technology (ICT) tools that necessary and useful in education explained [2]. According to [15], the knowledge of ICT usage improves human capacity in every fields of human endeavor such as educational programmes and activities. In the last two decades, the higher institutions have invested heavily in ICT tools by procuring facilities such as projectors, installation of internet facilities and importantly the purchase of computers for teaching and learning processes. In [14], the advantages of using technology in education include: making learner more interested, decreases learning time and provide opportunities to learn in non-traditional methods.

The significance of computers cannot be overemphasized in education. Computers have been generally accepted as modern instruments that enable the teachers/lecturers to select the teaching methods that will increase students' (learners') interest in learning. Computer is an electromechanical device designed to sequentially accept, process and store data on the basis of set of instructions to produce useful information. The students' academic performance can be referred to as the competencies, skills acquired and attitudes learned through the education experience.

The direct link between computer as resource utilization and students' academic performance was in the heart of an extensive literature during the last two decades. Several studies have tried to explain the roles 
the added values of those technologies in classrooms and on students' performances. Since the internet revolution, there is a shift in the literature that focuses more on the impact of online activities; use internet; use of educative online platforms; digital devices such as phones, calculators etc in education. According to [5], these new technologies are central to contemporary society and therefore referred to this era as information technology age. Reference [12] pointed out that the education community is not left out in the consequences of computer utilization on academic performance of students. He highlighted the benefits of computers in teaching and learning activities as follow:

i. Increase students' motivation towards learning

ii. Encourage use of peer coaching and peer review (group discussion)

iii. Improve teachers' and students' quality of work

iv. Develop communication and vocational skills

v. Improve poor handwriting and languages skills through word processing

vi. Facilitate teachers practices, planning tools and assessment rubrics

vii. Enhance student's assimilation through graphics (pictures) and audio-visual application that shapes educational outcomes

viii. Enhance academic performance due to the reinforcement and practice that computer afforded

Reference [11] shows the factors that affect students' academic performances include teachers' characteristics, students' characteristics, educational environment, selection of teaching/instructional aids, utilization of instructional materials/resources, selection of suitable teaching methods, government policies on education, etc.

Reference [9] showed that there is no evidence relationship between increased educational use of computers and students' performance. In fact, his findings showed a consistently negative and marginally significant relationship between computers' applications and some students' achievement. Reference [8] revealed that on average, students who use computer-based instruction scored higher than students without computers. The students also learnt more in less time.

\section{LITERATURE REVIEW}

Researchers have commented immensely in the use of computer-driven instructional aids in any educational processes, that the use cannot be over-emphasized. Moreover, links have been made between computer use and constructivist, collaborative, and inquiry-based learning and also pedagogical change [16]. Some researchers suggest that computer technology can overhaul education, serving as a panacea, or as an agent of change. Generally, it is accepted that computers have the potential to enhance teaching and learning [17] and provide students with a learning experience that other strategies cannot provide [18].
Reference [7] added that, the importance of instructional materials for both teacher and students cannot be over emphasized. The use of computer-driven instructional aids is essential to support teaching and learning because other phenomenal cannot be easily expressed without the support of graphics maps, video, pictures etc.

\section{A. Stimulation Of Students' Interest}

In teaching-learning process, there is the need to generate, arouse, motivate and maintain students' interest. Reference [1] agreed and based on investigations that pictures stimulates and help further study, helps students to take active interest in the topic presented.

\section{B. Concretize abstract issues or topics in teaching and learning Process}

The use of computer in teaching and learning process makes learning real, practical and more permanents to the learners. Reference [10] stated that instructional materials were valuable assets in learning situations because they make lesions practical and realistic. They are the pivots on which the wheels of the teaching-learning process rotate.

\section{Creating of effective communication}

Computer-driven instructional aids if properly used allow for a flow and transmission of ideal from the teacher to the students and likewise from the students to the teacher or from one group to other. The learners will be able to see, touch, spell what is been talked about by the teacher and be curious to ask questions that would be very helpful for effective evaluation (formative) of the teacher and instructions in subject matter. The table 2 shows some educational and computer-driven instructional materials as highlighted by [10].

Table 1. List of some educational technology and computer-driven instructional aids

\begin{tabular}{|l|l|l|l|}
\hline S/N & Flexible & Fixed/mobile & Mobile \\
\hline 1 & Television & Computer Mobile & Phones \\
\hline 2 & $\begin{array}{l}\text { Satellite } \\
\text { Receivers }\end{array}$ & Storage Devices & $\begin{array}{l}\text { Memory } \\
\text { Reader }\end{array}$ \\
\hline 3 & Radio & Internet/ email/ social media & iPod \\
\hline 4 & Recorders & $\begin{array}{l}\text { Smart Boards / Touch } \\
\text { screens }\end{array}$ & iPads \\
\hline 5 & Video & Plain Screens & Androids \\
\hline 6 & Projectors & Robots & Iphone \\
\hline 7 & Video Games & Avatars & PDAs \\
\hline
\end{tabular}

In one study, Internet usage was categorized in two empirical factors, namely usage profile such reason for using the Internet, average daily use of the Internet and usage patterns like average daily use of the Internet for communication/e-mailing/chat, information access/ downloading/entertainment and electronic services [20]. These factors have something to do with the present study which dealt with the differences in the attributes of the students enrolled in board and non-board degree programs. According to [22], defining the characteristics 
of students enrolled in these two different degree programs has never been explored rigorously especially in dealing with computer utilization. Different college degree board programs have various means of screening the students who can be allowed to enroll and pursue it until graduation. Those who did not pass the qualifying exam have to take the non-board degree program of their choice [19]. But most students take college degrees without government examination like business administration, communication arts, hospitality management, computer science, computer engineering, information technology, and industrial engineering [19].

Reference [19] stated that the use of digital technology most recently, on-the-go for recreational purposes, has increased among youth over the past 15 years. Children and adolescent between the ages of 8 to 18 years spend an average of 5-6 hours per day using information and communication technologies. It is a useful progress because of the increase of internet usage which is unlimited, uncontrolled and uninhibited and easiness which arrival all sorts of to information or persons but this state can cause to some important negative results too [21]. Due to long hours of staying in front of the computers either for educational and entertainment purposes, college students represent a particularly vulnerable group of having frequent interpersonal and academic conflicts, and physical health-threatening risks related to problem Internet use [22]. The extent of its effect on the present study in terms of academic performance, health and behaviour might vary to the two different groups of students under investigation [19].

Reference [28] offered three explanations for the equivocal findings with respect to computer-based instruction and school performance. First, variability in hardware and software among schools participating in the research may explain the equivocal findings. Second, the failure of schools to accompany technology use with concurrent reforms in the other areas, such as curriculum and teacher professional development, may explain the failure to find beneficial effects of technology use on academic performance. Third, the lack of rigorous, structured longitudinal studies may explain the failure to find positive effects of computer-based instruction, as well as information technology use in general, on academic performance. Rochelle and colleagues suggest that positive effects are most likely to emerge when technology is used to support the four fundamentals of learning: active engagement, participation in groups, frequent interaction and feedback, and connections to real-world contexts [28].

Other findings point to a relationship between technology use and academic performance, although causal relationships have been difficult to establish as reported by reference [23]. Several studies show that the presence of educational resources in the home, including computers, is a strong predictor of academic success in mathematics and science [23]. Having a home computer has been associated with higher test scores in reading, even after controlling for family income and other factors related to reading test scores [24]. Still other findings indicate that participating in a networked community of learners improves educational outcomes for at-risk children [25]. Some researchers have even suggested that recent nationwide increases in nonverbal intelligence test scores may be attributable to "exposure to the proliferation of imagery in electronic technology" [23]. Overall, whether using computer-based technology contributes to children's academic performance remains uncertain [26]. Reference [27] suggested that having a home computer is linked to better academic performance.

\section{StATEMEnt Of The Problem}

The development of any nation in the world rests on her education; and the future of our nation lies in the hand of the youths (students) who are the leaders of tomorrow. How do these students acquire knowledge in the classroom for future challenges? Reference [3] examined the relationship between having a home computer and school performance, for a sample of approximately 64,300 students in the United States. Their findings confirmed that students who have access to a computer at home for educational purpose demonstrated improved scores in computer science and mathematics. This acquisition helps the students to develop the technological and logical skills in problem-solving process. The interest has been on how to use computers to support teaching methods in order to enhance motivation in learning, students' characteristics as well as teachers. Do technological advancement which involves application of computer to study, affects students' attainment of educational goals? This study is therefore designed to investigate the perception of students on computer utilization and academic performance in the north-central geopolitical zone of Nigeria.

\section{Aim AND OBJectives}

The use of technology to support teaching and learning have become essential skills for the professional teachers and the learners in today's world. The integration of computers in schools is needed in order to accomplish many educational objectives and improve the quality of lessons in all subject areas that enhance teachers' productivities as discussed by the educational researchers. The aim of this study is to investigate the perception students on computer utilization and academic performance in the Colleges of Education in the NorthCentral geopolitical zone. In addition, it will also achieve the followings:

i. To examine if students who utilize computers perform academically above average.

ii. To investigate if there is any significant difference between computer utilization and students' academic performance.

iii. To investigate if there is any significant relationship in the performance of male and female students who utilize computers. 
The findings and recommendations of the study aim at providing workable solutions that enhance the achievement of educational objectives.

\section{RESEARCH QUESTIONS}

The following questions were asked to guide the conduct of the study:

i. What is the perception of students on computer utilization and academic performance?

ii. Do students who utilize computers perform academically above average?

\section{HYPOTHESES}

Two null hypotheses were postulated for the study:

i. There is no significant difference between computer utilization and students' academic performance.

ii. There is no significant difference in the performance of male and female students who utilize computers.

iii. There is no significant difference in the perception of students on computer utilization and their academic performance on the basis of Colleges of Education.

\section{METHODOLOGY}

The methods adopted for the study were discussed under the following sub-headings:

\section{RESEARCH DESIGN}

The study was a descriptive research design with emphasis on survey approach. This was adopted to enable the researcher gather relevant data on the perception of students on computer utilization and academic performance.

\section{Population AND SAMPle}

The population comprised all Colleges of Education in North Central geopolitical zone of Nigeria: made up of six states and FCT-Abuja, out of which six Colleges were selected as sample on the basis of one College from each state.

The Table 2 shows the names and states of the selected Colleges of Education in the North-Central geopolitical zone of Nigeria.

The selection of the respondents was done through simple random sampling technique on the basis of 100 students from each College. Therefore, a total of six hundred (600) respondents constituted the sample. This is made up male and female students.
Table 2. Name of Colleges of Education and their respective States

\begin{tabular}{lll}
\hline s/n & Name of College & State \\
\hline $\mathbf{1 .}$ & FCT COE, Abuja & FCT-Abuja \\
2. & Federal COE, Okene & Kogi \\
3. & Nassarawa State COE, Akwanga & Nassarawa \\
$\mathbf{4 .}$ & Kwara State COE, Oro & Kwara \\
$\mathbf{5 .}$ & Niger State COE, Minna & Niger \\
6. & Federal COE, Pankshin & Plateau \\
\hline *COE: College of Education &
\end{tabular}

\section{RESEARCH INSTRUMENT}

The instrument used for data collection was a questionnaire designed by the researcher and titled "Computer Utilization and Students' Academic Performance Questionnaire" (CUSAPQ). The questionnaire was administered by the researcher and twelve (12) research assistants for easier data collection. The CUSAPQ consisted two (2) sections A and B. Section A was designed to elicit personal information on the respondents such as gender while Section B had 20 items to elicit responses on computer utilization with respect to academic performance. The validation of the instrument was done through expert judgement to establish the face and construct validity and the necessary modifications and corrections were done. A re-test method was used to estimate the reliability co-efficient at two (2) weeks interval and it was found to be 0.86 . This was considered reliable thus suitable for the study. The instrument was scored on the basis of four-point scale of 4, 3, 2 and 1. Since the items were 20, the minimum and maximum mean-scores obtainable were 20 and 80 respectively a copy of the questionnaire.

\section{DATA ANALYSIS}

The data collected were analysed using frequency count and percentages. The null hypotheses postulated for the study were tested using Chi-square and ANOVA statistical analysis at 0.05 level of significance.

\section{RESULTS}

The results of data analysis on research questions and testing of hypotheses are presented in tables 3 to 7 . Out of the 600 questionnaires administered, only 551 $(91.83 \%)$ were found suitable for analysis.

Other forms were either not returned/collected or not properly filled by the respondents.

Research question 1: What is the perception of students on computer utilization and academic performance?

Table 3 shows the frequency and percentages of the respondents for each item on the students' perception on computer utilization and students' academic performance. The table indicates average percentages of $44.35 \%$, 
$33.33 \%, \quad 13.07 \%$ and $9.26 \%$ for "Strongly Agree", "Agree", "Disagree" and "Strongly Disagree" respectively. Accordingly, about $77.68 \%$ of the respondents agreed with the researcher that computer utilization enhances teaching and learning process towards achieving higher academic performance.
However, about $22.32 \%$ of the respondents disagreed with the researcher on the students' perception on computer utilization and students' academic performance. Based on these percentages, it therefore means that computer utilization in learning affect students' academic performance positively.

Table 3. Frequency count and percentage analysis of students' perception on computer utilization and students' academic performance

\begin{tabular}{|c|c|c|c|c|c|}
\hline $\mathbf{s} / \mathbf{n}$ & Items & \begin{tabular}{c}
\multicolumn{2}{c}{$\mathbf{S A}$} \\
$\mathbf{F} \quad[\%]$
\end{tabular} & $\begin{array}{ll} & \mathbf{A} \\
\mathbf{F} & {[\%]}\end{array}$ & $\begin{array}{ll} & \text { D } \\
\mathbf{F} & {[\%]}\end{array}$ & $\begin{array}{c}\text { SD } \\
\text { F }[\%]\end{array}$ \\
\hline a. & Computer fascinates students and makes learning interesting & $\begin{array}{c}361 \\
{[65.52]}\end{array}$ & $\begin{array}{c}183 \\
{[33.21]}\end{array}$ & $\begin{array}{c}4 \\
{[0.73]}\end{array}$ & $\begin{array}{c}3 \\
{[0.54]}\end{array}$ \\
\hline b. & Computer in the learning process often results in a deeper focus and concentration & $\begin{array}{c}359 \\
{[65.15]}\end{array}$ & $\begin{array}{c}172 \\
{[31.22]}\end{array}$ & $\begin{array}{c}15 \\
{[2.72} \\
\end{array}$ & $\begin{array}{c}5 \\
{[0.91]}\end{array}$ \\
\hline c. & Computer enhances students' rate of assimilation & $\begin{array}{c}259 \\
{[47.01]}\end{array}$ & $\begin{array}{c}286 \\
{[51.91]}\end{array}$ & $\begin{array}{c}2 \\
{[0.36]}\end{array}$ & $\begin{array}{c}4 \\
{[0.73]}\end{array}$ \\
\hline d. & Computer makes learning fast & $\begin{array}{c}279 \\
{[50.64]}\end{array}$ & $\begin{array}{c}269 \\
{[48.82]}\end{array}$ & $\begin{array}{c}2 \\
{[0.36]} \\
\end{array}$ & $\begin{array}{c}1 \\
{[0.18]}\end{array}$ \\
\hline e. & Computer develops effective communication technique & $\begin{array}{c}91 \\
{[16.52]}\end{array}$ & $\begin{array}{c}93 \\
{[16.88]}\end{array}$ & $\begin{array}{c}181 \\
{[32.85]}\end{array}$ & $\begin{array}{c}186 \\
{[33.76]}\end{array}$ \\
\hline f. & Computer enhances students' computational skills and logical reasoning & $\begin{array}{c}348 \\
{[63.16]}\end{array}$ & $\begin{array}{c}195 \\
{[35.39]}\end{array}$ & $\begin{array}{c}3 \\
{[0.54]}\end{array}$ & $\begin{array}{c}5 \\
{[0.91]}\end{array}$ \\
\hline g. & Computer allows students to learn independently & $\begin{array}{c}289 \\
{[52.45]}\end{array}$ & $\begin{array}{c}242 \\
{[43.92]}\end{array}$ & $\begin{array}{c}13 \\
{[2.36]}\end{array}$ & $\begin{array}{c}7 \\
{[1.27]} \\
\end{array}$ \\
\hline h. & Computer improves students' quality of work & $\begin{array}{c}79 \\
{[14.34]} \\
\end{array}$ & $\begin{array}{c}95 \\
{[17.24]} \\
\end{array}$ & $\begin{array}{c}184 \\
{[33.39]}\end{array}$ & $\begin{array}{c}193 \\
{[35.03]}\end{array}$ \\
\hline i. & Computer in the learning gives students more control in the classroom & $\begin{array}{c}355 \\
{[64.43]}\end{array}$ & $\begin{array}{c}190 \\
{[34.48]}\end{array}$ & $\begin{array}{c}4 \\
{[0.73]}\end{array}$ & $\begin{array}{c}2 \\
{[0.36]}\end{array}$ \\
\hline j. & Computer increases retention of information & $\begin{array}{c}102 \\
{[18.51]}\end{array}$ & $\begin{array}{c}88 \\
{[15.97]} \\
\end{array}$ & $\begin{array}{c}198 \\
{[35.93]}\end{array}$ & $\begin{array}{c}163 \\
{[29.58]}\end{array}$ \\
\hline $\mathrm{k}$. & Computer encourages use of peer coaching and reviews of lessons & $\begin{array}{c}339 \\
{[61.52]}\end{array}$ & $\begin{array}{c}192 \\
{[34.85]}\end{array}$ & 12 [2.18] & $\begin{array}{c}8 \\
{[1.45]}\end{array}$ \\
\hline 1. & Computer in the learning encourages academic laziness & $\begin{array}{c}31 \\
{[5.63]}\end{array}$ & $\begin{array}{c}67 \\
{[12.16]} \\
\end{array}$ & $\begin{array}{c}279 \\
{[50.64]} \\
\end{array}$ & $\begin{array}{c}174 \\
{[31.58]} \\
\end{array}$ \\
\hline $\mathrm{m}$. & Computer enhances students' participation in the learning process actively & $\begin{array}{c}288 \\
{[52.27]}\end{array}$ & $\begin{array}{c}255 \\
{[46.28]}\end{array}$ & $\begin{array}{c}3 \\
{[0.54]}\end{array}$ & $\begin{array}{c}5 \\
{[0.91]}\end{array}$ \\
\hline n. & Concretize abstract issues or topics in teaching and learning process & $\begin{array}{c}213 \\
{[38.66]}\end{array}$ & $\begin{array}{c}206 \\
{[37.39]}\end{array}$ & $\begin{array}{l}107 \\
{[19.42]}\end{array}$ & 25 [4.54] \\
\hline o. & Providing meaning and useful sources of information to teachers and learners & $\begin{array}{c}291 \\
{[51.00]}\end{array}$ & $\begin{array}{c}238 \\
{[43.19]}\end{array}$ & $\begin{array}{c}23 \\
{[4.17]}\end{array}$ & $\begin{array}{c}9 \\
{[1.63]}\end{array}$ \\
\hline p. & It helps in developing a continuity of reasoning and coherence of thought & $\begin{array}{c}148 \\
{[26.86]}\end{array}$ & $\begin{array}{c}178 \\
{[32.30]}\end{array}$ & $\begin{array}{c}144 \\
{[26.13]}\end{array}$ & $\begin{array}{c}81 \\
{[14.70]}\end{array}$ \\
\hline q. & It saves time and reduces verbalism or repletion of words & $\begin{array}{c}151 \\
{[27.40]}\end{array}$ & $\begin{array}{c}82 \\
{[14.88]}\end{array}$ & $\begin{array}{c}201 \\
{[36.48]}\end{array}$ & $\begin{array}{c}117 \\
{[21.23]}\end{array}$ \\
\hline r. & computer improves teaching and learning techniques & $\begin{array}{c}251 \\
{[45.55]}\end{array}$ & $\begin{array}{c}284 \\
{[51.54]}\end{array}$ & $\begin{array}{c}5 \\
{[0.91]}\end{array}$ & $\begin{array}{c}11 \\
{[2.00]}\end{array}$ \\
\hline s. & Computer promotes closer academic relations between the teacher and students & $\begin{array}{c}304 \\
{[55.17]} \\
\end{array}$ & $\begin{array}{c}205 \\
{[37.21]}\end{array}$ & $\begin{array}{c}28 \\
{[5.08]}\end{array}$ & $\begin{array}{c}14 \\
{[2.54]}\end{array}$ \\
\hline t. & $\begin{array}{l}\text { Computer makes it easier to access educational resources towards achieving } \\
\text { academic excellence }\end{array}$ & $\begin{array}{c}359 \\
{[65.15]}\end{array}$ & $\begin{array}{c}153 \\
{[27.77]}\end{array}$ & $\begin{array}{c}32 \\
{[5.81]}\end{array}$ & $\begin{array}{c}7 \\
{[1.27]}\end{array}$ \\
\hline
\end{tabular}

Research question 2: Do students who utilize computers perform academically above average?

Table 4. Frequency count and percentage analysis of computer utilization and students' academic performance

\begin{tabular}{llccc}
\hline computer & \multicolumn{4}{c}{ Academic Performance } \\
& $\mathbf{N}$ & High & Average & Low \\
\hline Usage & 375 & 268 & 83 & 24 \\
& & {$[71.47]$} & {$[22.13]$} & {$[6.4]$} \\
Non-usage & 176 & 21 & 64 & 91 \\
& & {$[11.93]$} & {$[36.36]$} & {$[51.71]$} \\
Total & 551 & 289 & 147 & 115 \\
\hline
\end{tabular}

The table 4 shows that majority of the students (respondents) $(71.47 \%)$ who utilized computer in the learning activities had high academic performance, only few $22.13 \%$ performed at average level while $6.4 \%$ of the students had their academic performance low with utilization of computers. The table 4 also indicates that $11.93 \%$ of the students who did not utilize computer had their academic perform high. Significantly, the table shows that students who utilize computer performed academically above average in the school.

\section{Testing OF Hypotheses}

The stated null hypotheses were subjected to test as follow at 0.05 level of significance. 
$\mathrm{H}_{01}$ : There is no significant difference between computer utilization and students' academic performance.

Table 5 shows that the calculated $\mathrm{X}^{2}$ value of 207.83 is greater than the critical value of 5.99. This means that there is a significant relationship between computer utilization and students' academic performance $\left[\mathrm{X}^{2}=\right.$ $207.83<\mathrm{P}<0.05 ; \mathrm{df}=2]$. Therefore, the null rejected

replaced with an alternate hypothesis.

Table 5. Chi-square test between computer utilization and students' academic performance

\begin{tabular}{llllllll}
\hline CPT & \multicolumn{5}{c}{ Academic Performance } & & \\
& $\mathbf{N}$ & High & Average & Low & Df & Cal. $\mathbf{x}^{2}$ & Crt. $\mathbf{x}^{2}$ \\
\hline Usage & 375 & 268 & 83 & 24 & & & \\
& & {$[71.47]$} & {$[22.13]$} & {$[6.4]$} & & & \\
& & & & & 207.83 & 5.99 \\
NU & 176 & 21 & 64 & 91 & & \\
& & {$[11.93]$} & {$[36.36]$} & {$[51.71]$} & & \\
Total & 551 & 289 & 147 & 115 & & \\
\hline$P=0.05,{ }^{*}$ CPT: Computer, NU: Non-Usage, Crt: Critical
\end{tabular}

$\mathrm{H}_{02}$ : There is no significant difference in the performance of male and female students who utilize computers.

Table 6. Chi-square test between computer utilization and students' academic performance on the basis of gender

\begin{tabular}{llllllll}
\hline Gende & \multicolumn{9}{c}{ Academic Performance } & & \\
$\mathbf{r}$ & $\mathbf{N}$ & High & Average & Low & Df & Cal. $\mathbf{x}^{2}$ & Crt. $\mathbf{x}^{2}$ \\
\hline Male & 307 & 179 & 72 & 56 & & & \\
& & {$[173.28]$} & {$[72.99]$} & {$[60.73]$} & & & \\
& & & & & 2 & 1.29 & 5.99 \\
Femal & 244 & 132 & 59 & 53 & & & \\
$\mathbf{e}$ & & {$[137.72]$} & {$[58.01]$} & {$[48.27]$} & & \\
Total & 551 & 311 & 131 & 109 & & \\
\hline$P=0.05$ & & & & & &
\end{tabular}

Table 6 shows that the calculated $\mathrm{X}^{2}$ value of 1.29 is lesser than the critical value of 5.99. This means that there is no significant relationship between computer utilization and students' academic performance $\left[\mathrm{X}^{2}=\right.$ $1.29>\mathrm{P}<0.05 ; \mathrm{df}=2$ ]. Therefore, the null hypothesis was accepted.

$\mathrm{H}_{03}$ : There is no significant difference in the perception of students on computer utilization and their academic performance on the basis of Colleges of Education.

Table 7. ANOVA analysis on the computer utilization and students' academic performance on the basis of Colleges of Education

\begin{tabular}{llllll}
\hline $\begin{array}{l}\text { Sources of } \\
\text { variation }\end{array}$ & SS & D $\boldsymbol{f}$ & MS & F-Ratio & F-Crt \\
\hline $\begin{array}{l}\text { Between } \\
\text { COE }\end{array}$ & 232.18 & 5 & 46.44 & & \\
& & & & & \\
Within & 23482.2 & 54 & 43.09 & 53 & 2.23 \\
COE & 4 & 5 & & & \\
Total & 23714.4 & 55 & & & \\
& 2 & 0 & & & \\
\hline$P=0.05$ & & & &
\end{tabular}

$P=0.05$
The table 7 shows the critical value of 2.23 based on 5 and 545 degrees of freedom and p-value of 0.05. Since the calculated value of 1.54 is less than the critical value, the hypothesis was accepted. This means that there is no significant difference in the students' perception on computer utilization and academic performance on the basis of Colleges of Education.

\section{Discussion Of RESUlts}

Findings from analysed data as presented in table 3 shows that computer utilization affects the academic performance of students in the Colleges of Education in the North-Central geopolitical zone positively. This result agreed with [3] findings which showed positive perception of computer utilization on students' academic performance in the selected zone.

Table 4 indicated that students who utilize computers performed academically above average in the school and this result answered the research question 2. This finding is similar to [6] which indicated positive perception of computer utilization on students' academic performance.

The table 5 indicated that there is a significant difference between computer utilization and students' academic performance. This is similar to the [8] findings which showed that students who use computer-based instruction scored higher than students without computers. Table 6 showed that there is no significant difference in the academic performance of male and female students who utilize computers. The result is different from the study of [4] that indicated that male students performed significantly higher than females towards computer utilization on academic performance.

Table 7 indicates that there is no significant difference in the students' perception on computer utilization and academic performance on the basis of Colleges of Education. The findings revealed that computer utilization affects the academic performance of students in the Colleges of Education in the North-Central geopolitical zone positively.

\section{CONCLUSION}

In conclusion, the relationship between the utilization of computers and students' academic performance is very significant. The utilization of computers had motivated students to commit to learning and participate actively in the teaching and learning activities. The findings of the study revealed positive perception of computer utilization and students' academic performance in the selected Colleges of Education of north-central geographical zone of Nigeria.

\section{REFERENCES}

[1] J. M. Anyanwu, "The effectiveness of instructional materials in teaching of social studies in some selected post primary school in Owerri educational zone Imo State", (B. ed) Research Project Unpublished, 2008. 
[2] A. W. Astin, "Student involvement: A development theory for high education," Journal of College Student Development. 4, 518-529., 2011.

[3] P. Attwell, and J. Battle,"Home computer and school performance", The Information Society. 15, 1-10, June, 2012.

[4] H. J. Becker, "Pedagogical motivations for student computer use that leads to student engagement," Education Technology. 40(5), 5-17., 2012.

[5] D. Coates, and B. R. Humphreys, "No significant distance between face-to-face and online instruction. Evidence from principles of economic," Economic of Education Review. 23 (6), 533-546., 2009.

[6] T. Fuchs, and L. Woessman, "Computer and students learning: bivariate and mutltivariate evidence on the availability and use of computers at home and at school, CESifo Working Paper, 1321-1335., 2011.

[7] M. A. Kamba,"Problems, challenges and benefits of implementing e-learning in Nigerian universities: an empirical study", International Journal of Emerging Technologies in Learning. 2 (1), 123-128.. 2011.

[8] J. A. Kulik, "Meta-analysis study of findings on computer-based instruction", In E. L. Baker and HF O'Neil Technology Assessment in education and training, Hillsdale, NJ:Lawrence Erlbaum, 2010.

[9] E. L. Leuven,"The effect of extra funding for disadvantaged pupils on achievement", IZA Discussion Paper. No. 1122. Bonn, Germany: Institute for the Study of Labor, 2013.

[10] L. A. Ogunsola,"Information communication technologies and the effects of globalization: twentyfirstcentury "digital slavery" for developing countriesmyth or reality", Electronic Journal of Academic and Special Librarianship 6 (1); pp. 1-10., August 2008.

[11] B. Olobamise,"The information society and Nigeria. Development Information Network Nigeria", Retrieved on $20^{\text {th }} \quad$ May, 2014 from http://www.jidaw. com/nigeria/devnet1.htm1, 2012.

[12] J. E. Rockoff, "The impact of individual teacher on students' achievement: evidence from panel data", American Economic Review Paper and Proceedings, 94 (2), 247-252., April 2010.

[13] Y. Aharon, "Improve abstract reasoning in computer introductory courses," International Journal of Modern Education and Computer Science (IJMECS), 1, pp. 14-20, 2013.

[14] P. G. Abbas, "Teachers' use of technology and constructivism," International Journal of Modern Education and Computer Science(IJMECS),4, 49-63. 2013.

[15] N. D. Oye, M. C. Obi, and T. N. Mohd, "Guidance and counseling in Nigerian secondary schools: the role of ICT," International Journal of Modern Education and Computer Science (IJMECS); 8, 26-33., 2012.

[16] P. Scrimshaw, "Enabling teachers to make successful use of information communication and technology," coventry: Becta. Retrieved on $8^{\text {th }}$ October, 2014 from http://www.becta.org.uk/research/display.cfm?section.

[17] J. Bhalla, "Computer use by school teachers in teachinglearning process," Journal of Education and Training Studies. Vol. 1, No. 2; 174-185, 2013.

[18] J. Wellington, "Has ICT come of age? Recurring debates on the role of ICT in Education," 1982-2004. Research in Science \& Technological Education, 23(1), 15-21, 2011.

[19] M. L., Jake (2013). Computer Utilization on Academic Performance, Health, and Behavior of Selected Students Enrolled in Board and Non-Board Degree Programs.
International Journal of Information and Education Technology (IACSIT), Vol. 3, No. 3, 382-387.

[20] I. Akman and A. Mishra, "Gender, age and income differences in internet usage among employees in organizations," Computers in Human Behavior, vol. 26, no. 3, pp. 482-490, May 2010.

[21] M. Kelleci, "The Effects of Internet Use, Cell Phones and Computer Games on Mental Health of Children and Adolescents," TAF Preventive Medicine Bulletin, vol. 7, no. 3, pp. 253-256, 2008.

[22] B. Rotsztein, "Problem Internet use and locus of control among college students: Preliminary findings," presented at The 35th Annual Conference of the New England Educational Research Organization, Portsmouth, New Hampshire, April 10, 2003.

[23] K. Subrahmanyam, R. E. Kraut, P. M. Greenfield, and E. F. Gross (2012). "The impact of home computer use on children's activities and development", 10, 123-144. Retrieved October, 2012.

[24] J. A. Kulik, "Meta-analytic studies of findings on computer-based instruction. Technology Assessment in Education and Training. Hillsdale, NJ: Erlbaum. 2010.

[25] M. Cole, "Cultural psychology: A once and future discipline", Cambridge, MA: Harvard University Press. 2006.

[26] M. K. Shields, and R. E. Behrman, "Children and computer technology: Analysis and recommendations," The Future of Children, Vol 10(2), 4-30, September 2010.

[27] B. Rocheleau, "Computer use by school-age children: Trends, patterns and predictors," Journal of Educational Computing Research, 1, 1-17, 2011.

[28] J. M. RoschellE, R. D. Pea, C. M. Hoadley, D. N. Gordon and B. M. Means, "Changing how and what children learn in school with computer-based technologies," Children and Computer Technology, 10(2), Pp76 -101., September 2012 .

\section{Authors' Profiles}

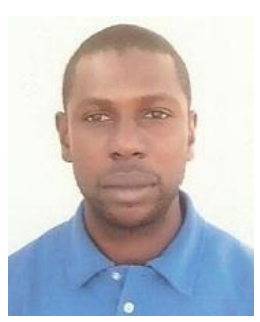

Salako, E. Adekunle has a degree in Electrical and Computer Engineering from Federal University of Technology, Minna, and PGDE from University of Maiduguri, all in Nigeria. He had worked as a System and Network Administrator with Nigerian Ports Authority (NPA).

$\mathrm{He}$ is currently a lecturer in the Department of Computer Science, School of Sciences, FCT College of Education, Zuba, FCTAbuja, Nigeria. In teaching, he has been focusing on computerization concepts to solve societal and educational problems.

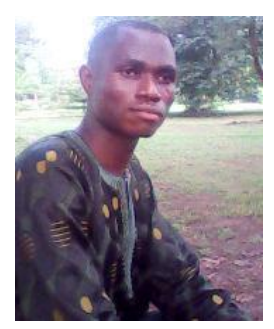

Solomon. A. Adepoju holds B.Tech (Mathematics/Computer Science) and M.Sc (Computer Science) from the Federal University of Technology, Minna and University of Ibadan respectively. His research interests include Human Computer Interaction, Web Mining and ICT4D. He is a member of Computer Professional Registration Council of Nigeria (CPN), IACSIT and IAENG 


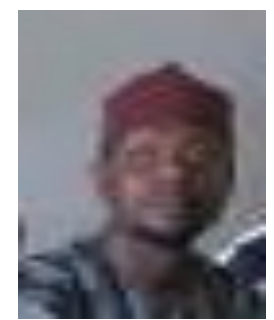

M. B. Abdullahi received B.Tech in communication security. Mathematics/Computer Science from Federal University of Technology, Minna- Nigeria and Ph.D. in Computer Science and Technology from Central South University, Changsha, Hunan, P.R.China. His current research interests include trust, security and privacy issues in data management for wireless sensor and adhoc networks, Internet and information and

How to cite this paper: Salako E. Adekunle, Solomon A. Adepoju, Muhammed B. Abdullahi,"Perception of Students on Computer Utilization and Academic Performance in the North-Central Geopolitical Zone of Nigeria", IJMECS, vol.7, no.4, pp.53-60, 2015.DOI: 10.5815/ijmecs.2015.04.06 